\title{
TEMPERATURE CONTROL CIRCUIT FOR SURFACE ACOUSTIC WAVE (SAW) RESONATORS
}

\author{
Z. M. ASHARI, F. SIDEK AND A. N. NORDIN \\ Electrical and Computer Engineering Department, Kulliyyah of Engineering, \\ International Islamic University Malaysia (IIUM), \\ Jalan Gombak, 53100 Kuala Lumpur, Malaysia. \\ zainab.ashari@student.iium.edu.my
}

\begin{abstract}
Surface Acoustic Wave (SAW) resonators are key components in oscillators, frequency synthesizers and transceivers. One of the drawbacks of a SAW resonator is that its piezoelectric substrate is highly sensitive to ambient temperatures which results in performance degradation. This work proposes a simple circuit design which stabilizes the temperature of a SAW resonator, making it independent of temperature changes. This circuit is based on the oven control method which elevates the temperature of the resonator to a temperature high enough for it to become tolerant to minor changes in ambient temperatures.The circuit consists of a temperature sensor, a heater and a comparator which turns the heater ON (or OFF) depending on the ambient temperature. Several SAW resonators are tested using this circuit and the experimental results indicate reduction in the Temperature Coefficient of Frequency (TCF from a maximum value of $130.44 /{ }^{\circ} \mathrm{C}$ to a minimum of $-1.11 /{ }^{\circ} \mathrm{C}$.
\end{abstract}

ABSTRAK : Akustik gelombang permukaan (SAW) resonator adalah komponen utama dalam osilator, pensintesis frekuensi dan penerima. Salah satu daripada kelemahan SAW ialah lapisan piezoelektrik teramat sensitif kepada suhu persekitaran yang menyebabkan kemerosotan prestasi. Kajian ini mencadangkan satu reka bentuk litar mudah yang menstabilkan suhu SAW resonator, menjadikannya bebas dari pengaruh perubahan suhu persekitaran. Litar ini adalah berdasarkan kaedah kawalan pemanas yang menaikkan suhu resonator kepada suhu yang cukup tinggi untuk menjadikannya toleran kepada perubahan kecil dalam suhu persekitaran. Litar ini terdiri daripada pengesan suhu, pemanas dan pembanding yang menukarkan pemanas kepada ON (atau OFF) bergantung kepada suhu persekitaran. Beberapa resonator SAW diuji dengan menggunakan litar ini dan keputusan uji kaji menunjukkan pengurangan dalam Pekali Suhu- Frekuensi (TCF dari nilai maksimum $130.44 /{ }^{\circ} \mathrm{C}$ untuk sekurang-kurangnya $-1.11 /{ }^{\circ} \mathrm{C}$.

KEYWORDS Temperature Control Circuit; Surface Acoustic Wave
Resonators; Temperature Coefficient of Frequency (TCF).

\section{INTRODUCTION}

Portable, handheld wireless communication devices are no longer luxury items, but are gradually becoming a necessity for modern human living. Increased popularity of such devices has led intensified demand for efficient and stable radio frequency (RF) components. Maturing significantly since its invention by Lord Raleigh in 1885, surface acoustic wave (SAW) devices have been gaining momentum as key players in existing 
RF transceiver systems. Resonators often function as intermediate frequency (IF), RF filters or as frequency synthesizers [1]. The wide use of such devices in the telecommunications industry are at astonishing levels, where approximately three billion acoustic wave filters are utilized annually [2].

Typically, Rayleigh wave resonators are highly sensitive to fluctuations in ambient temperatures, causing the resonant frequency of the device to vary with temperature. For device stability small variation of frequency with temperature (less than $1 \mathrm{ppm} /{ }^{\circ} \mathrm{C}$ ) is often desired. A variety of methods can be implemented to reduce the dependency of the device on temperature. Commonly used piezoelectric substrates of SAW resonators are quartz, Lithium tantalate $\left(\mathrm{LiTO}_{3}\right)$ and Lithium niobate $\left(\mathrm{LiNbO}_{3}\right)$. Variations in temperature will result in corresponding changes in resonant frequencies, causing the device to be unstable. The effect of temperature variations is represented by temperature coefficient of frequency (TCF), where a negative TCF indicates reduction of resonant frequency when the temperature is increased and vice-versa. SAW devices with TCFs of less than $1 \mathrm{ppm} /{ }^{\circ} \mathrm{C}$, are termed as temperature-stable.

Typical temperature compensation methods for SAW resonators are often complex, such as the usage of dual-resonators [3] which compensate temperature variations using two resonators with different SAW propagation directions. Another solution is to lay down positive $\mathrm{TCF} \mathrm{SiO}_{2}$ layers to compensate for the negative $\mathrm{ZnO}$ piezoelectric layer $[4]$.

Oven controlled crystal oscillators are usually used in applications which are expected to have very high degree of frequency stability [5]. The crystal oscillators show the high degree of stability even when the outside temperature is varied over a relatively larger range. For some other applications such as frequency control in telecommunication, even higher temperature stability is required.

The temperature stability is described as the change in frequency measured as $\Delta \mathrm{f} / \mathrm{f}$ (measured in ppm, parts per million) [6]. A better degree of stability can be achieved by placing the crystal in a thermally insulated container with a thermostatically controlled heater. When the crystal is heated to a temperature above the norm, it becomes independent of the fluctuations in the lower ambient temperatures [5].

For our research, a method similar to the micro-oven approach [7] is implemented. This technique is based on the principle of heating up the resonator to a temperature much higher than the ambient temperatures, making the resonator independent of small ambient temperature variations. A simple feedback circuit is used to turn the heating elements on or off, depending on the ambient temperatures, making the resonator's temperature stable and immune to ambient temperature variations. This paper first describes the SAW resonator device structure. The oven control method and temperature calibration of LM 35 is discussed next. Finally, the experimental results with improved temperature stability are shown. 


\section{THEORY AND CIRCUIT DESIGN}

Figure 1 shows the block diagram of SAW resonator temperature control circuit. LM35 precision centigrade temperature sensor is used to measure the ambient temperature. It provides an electrical output proportional to the ambient temperature which is fed into the comparator. The comparator acts as a controller circuit which turns the heaters on or off depending on the measured ambient temperature. $50{ }^{\circ} \mathrm{C}$ has been chosen as a constant temperature for the resonator to function. The output voltage of LM35 is connected to the input voltage of comparator circuit in order to maintain its temperature. The heaters are thermoelectric cooler devices which can generate heating or cooling based on the applied voltage. Positive applied voltage generates heat while negative applied voltage cools the device. This heater is placed in contact with the SAW resonator.

The comparator circuit compares the two voltage inputs signals and decides which one has greater voltage. In other words, if input voltage is less than reference voltage $(0.5$ $\mathrm{V})$, the output voltage of the comparator will flow to turn on the heater. The $0.5 \mathrm{~V}$ corresponds to the LM35's output voltage at temperature $50{ }^{\circ} \mathrm{C}$. If the ambient temperature is less than $50{ }^{\circ} \mathrm{C}$, the heater will heat the resonator until it attains the required temperature, $50^{\circ} \mathrm{C}$. Otherwise, the heater will be off when the input voltage of the comparator is greater than the reference voltage. This will occur when the resonator's temperature has been stabilized. The frequency stability of the SAW resonator can be observed through a network analyzer.

Acoustic wave resonators typically comprise of interdigital transducers (IDTs), reflectors and the piezoelectric substrate. Due to piezoelectricity, a propagating acoustic wave is generated in the surface of the substrate when a sinusoidal electrical signal is injected at the input transducers. These mechanical acoustic waves can be detected and converted back to electrical signals at the output electrodes. The presence of reflectors minimizes acoustic losses by containing the acoustic waves within a cavity.

When the resonator is heated, there is change in the resonance frequency, $\mathrm{f}_{\mathrm{r}}$. The dependence of resonant frequency versus temperature is based on (1).

$$
T C F=\frac{\Delta f}{f}\left(\frac{1}{\Delta T}\right) p p m /{ }^{\circ} C
$$

Where $T C F$ is the rate at which the frequency changes with temperature. $\triangle f$ is the change in resonant frequency, $f$ is the resonant frequency at room temperature and $\triangle T$ is the change in temperature. 


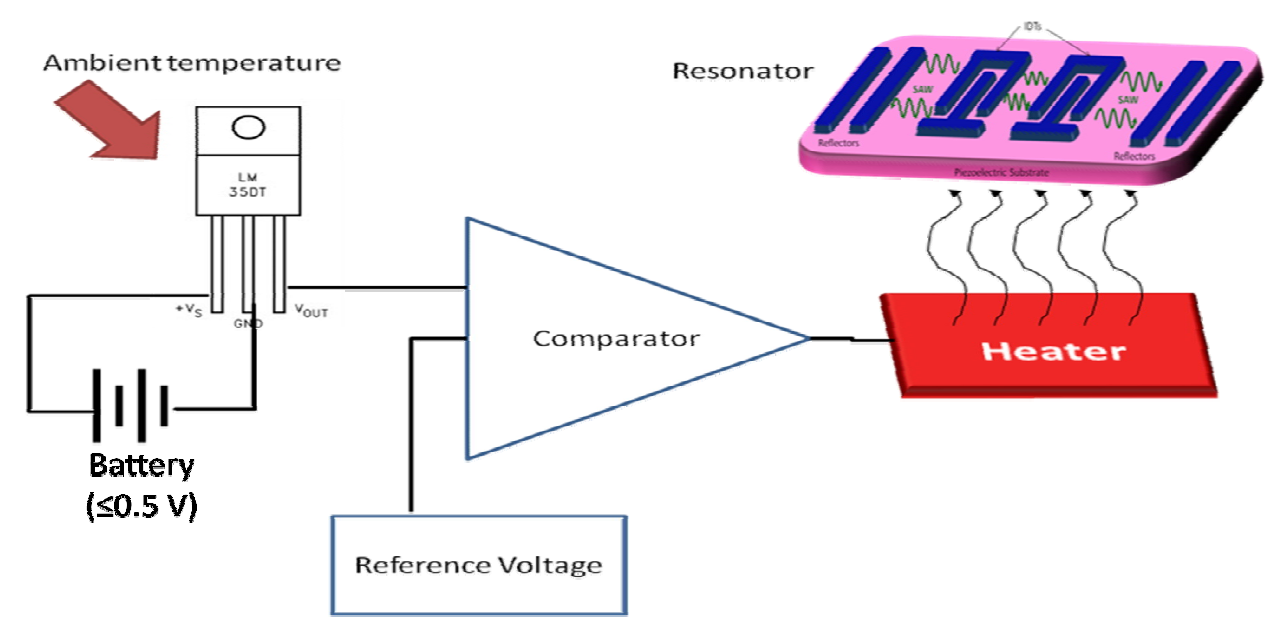

Fig.1: Block diagram of SAW resonator temperature control circuit.

\section{EXPERIMENTAL DETAILS}

Several SAW resonators with different center frequencies of $315.0 \mathrm{MHz}, 433.92 \mathrm{MHz}$ and $868.35 \mathrm{MHz}$ are used. Before constructing the complete circuit, the temperature sensor (LM 35) and Thermoelectric Cooler/Heater (TEC) need to be calibrated to determine the temperature characteristics of LM 35. When a certain input voltage is applied to the TEC, it will produce different temperature. The graph for temperature characteristic of LM 35 is shown in Fig 2.

The input temperature from TEC is proportional to the output voltage. A supply voltage of $1 \mathrm{~V}$ till $10 \mathrm{~V}$ was applied to the LM35. The output temperature is measured using digital multimeter and converted to temperature by a simple conversion factor as shown in equation (2). The measured slope for LM35 is $+10.0 \mathrm{mV} /{ }^{\circ} \mathrm{C}$.

Temperature $\left({ }^{\circ} \mathrm{C}\right)=\mathrm{V}_{\text {out }} *$ a conversion factor that is reciprocal $\left({ }^{\circ} \mathrm{C} / \mathrm{V}\right)$

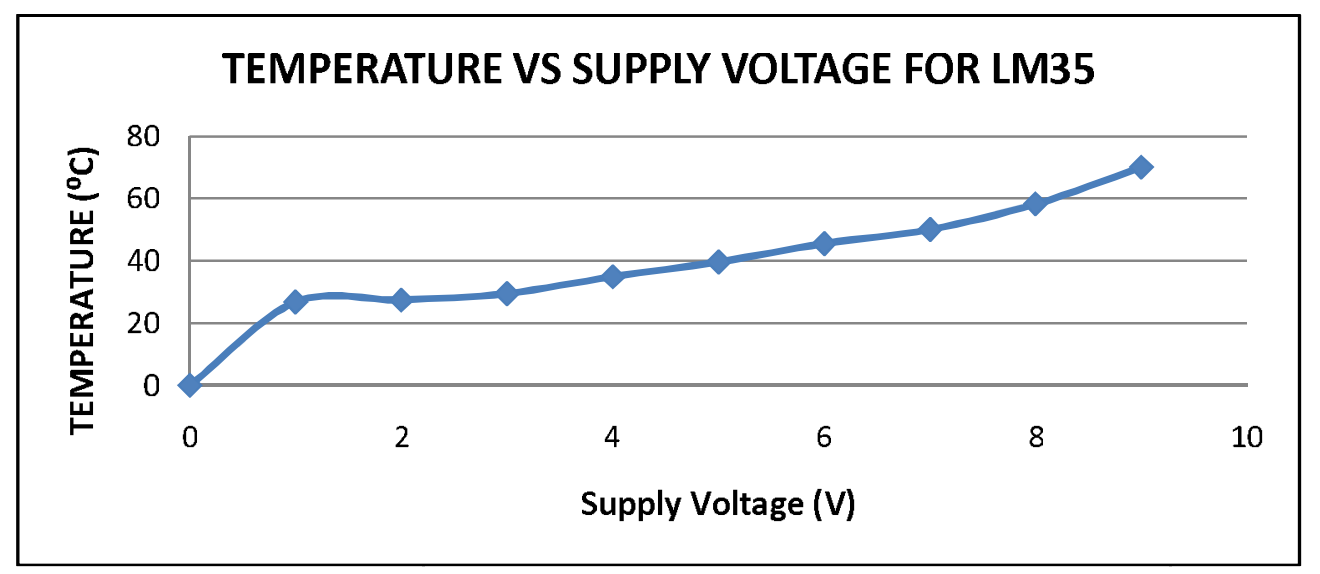

Fig. 2: The graph for temperature characteristic of LM 35 


\section{TEMPERATURE COMPENSATION CIRCUIT}

The experimental circuit consists of a simple circuit designed to stabilize the temperature of Surface Acoustic Wave Resonator. The components used in the design involves Temperature Sensor (LM 35), Thermo electric Cooler/Heater (TEC), Transistor (TIP31C), $1 \mathrm{k} \Omega$ Resistor, and also Operational Amplifier (LM 741) as shown in Fig. 3.

Once set to $50^{\circ} \mathrm{C}$, the SAW temperature is then controlled by the temperature control circuit. When the temperature of the SAW resonator drops below $50^{\circ} \mathrm{C}$ (Vin $<$ Vref), the heater is turned $\mathrm{ON}$ to stabilize the SAW resonator's temperature to $50^{\circ} \mathrm{C}$. In contrast, the heater will be turned off when the resonator's temperature rises to larger than $50^{\circ} \mathrm{C}$ (Vin > Vref). The opeational amplifier (LM35) functions as the comparator. An important component of the circuit is the comparator which compares the input voltage to a reference voltage of $0.5 \mathrm{~V}$.

The SAW resonator mounted on a printed circuit board, is connected to a network analyzer on one side and to a temperature control circuit on the other. The network analyzer shows the SAW resonator's measured frequency response. The detailed pictorial views are as shown in Fig. 4 and Fig. 5.
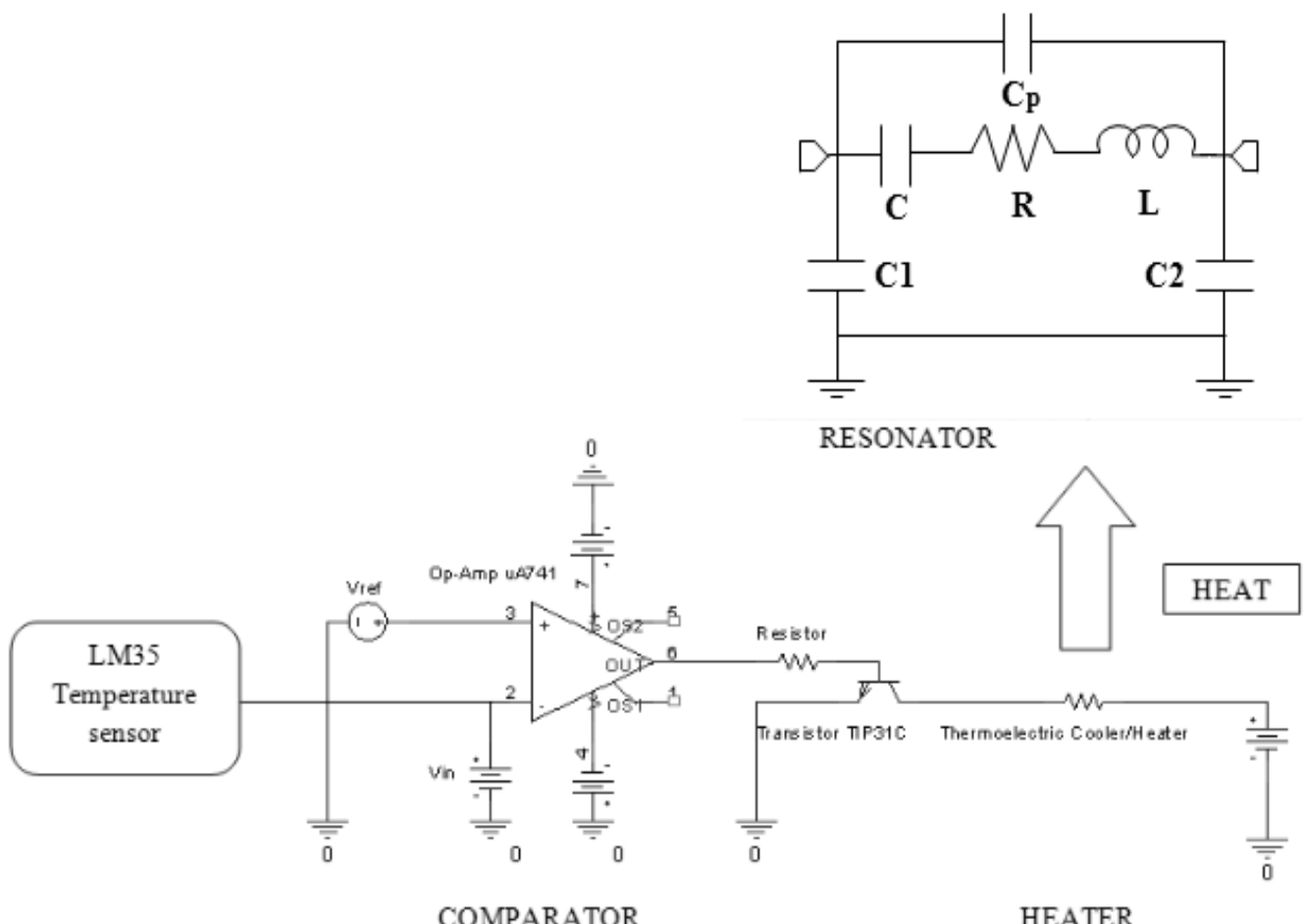

COMPARATOR

HEATER

Fig. 3: Circuit Design of Temperature Control Circuit for SAW Resonator. 


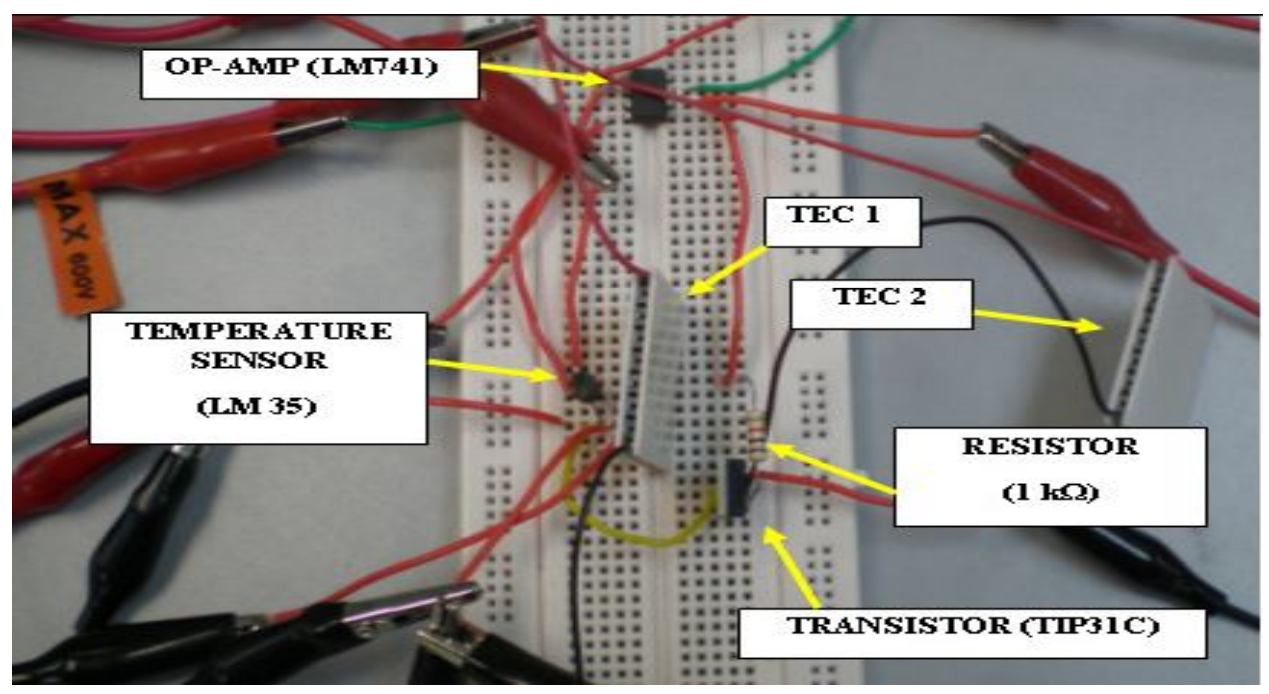

Fig. 4: Temperature Control Circuit.

Both parts of the SAW resonator are connected to the network analyzer using a PCB board and RF cables. This resonator circuit is placed in proximity with the temperature control circuit so that it can be heated by TEC. The network analyzer will measure the frequency resonance of the SAW resonator. The frequency response for each resonator is shown in Figs. 8 to 10.

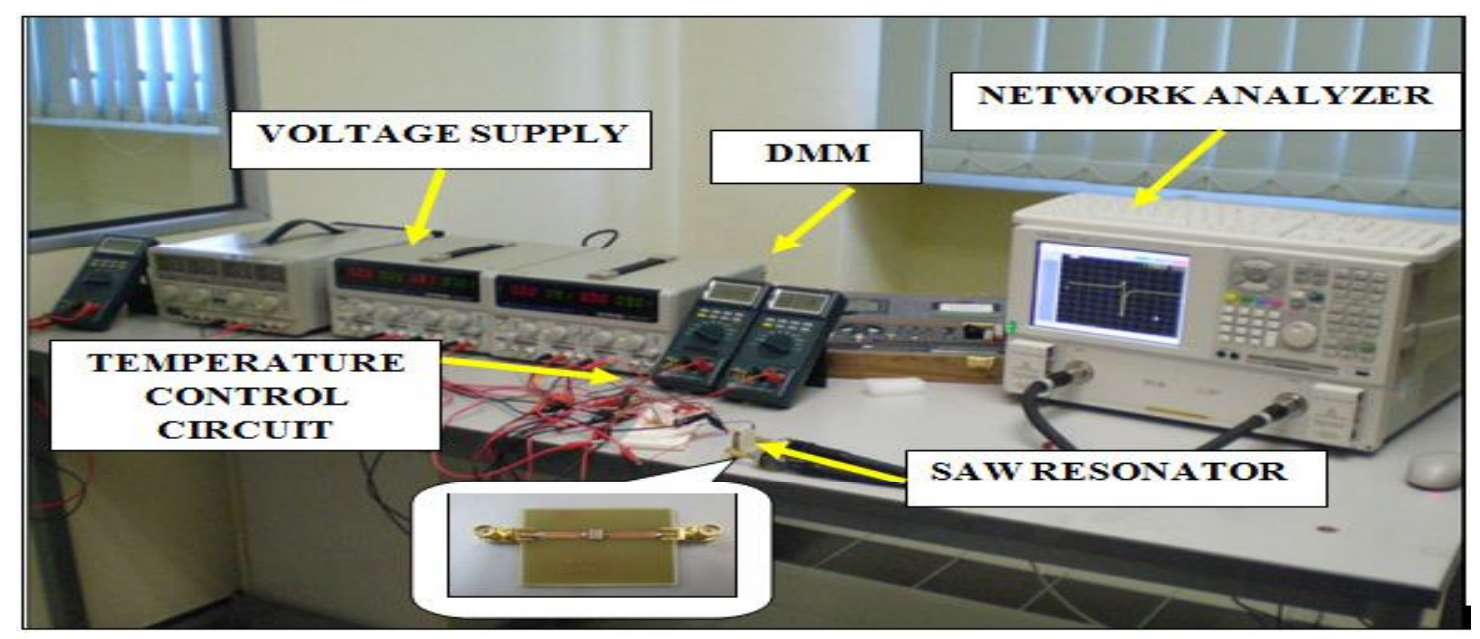

Fig. 5: Schematic test setup for frequency response measurement.

\section{SAW RESONATOR FREQUENCY RESPONSE MEASUREMENT}

The results obtained from the network analyzer verify that the frequency is constant due to implementation of the temperature control circuit at varying ambient temperatures. The temperature control circuit has successfully stabilized the operating temperature of SAW resonator. This can be clarified by referring to Fig. 6. Power consumption was 
calculated and found to be 5.81Watt for LM35, 0.90 Watt for the comparator and 2.50 Watt for the heater. Thus, the overall power consumed is 9.21 Watt.

\section{MODELLING OF SAW RESONATOR}

A theoretical equivalent circuit for the SAW resonator can be modeled as shown in Fig. 7 using Microwave Office software. The equivalent model consists of a series RLC circuit with parasitic capacitances $\left(\mathrm{C}_{1}, \mathrm{C}_{2}\right.$ and $\left.\mathrm{C}_{\mathrm{p}}\right)$. The series resonance is determined by the inductive ( $\mathrm{L}$ ) and capactive $(\mathrm{C})$ circuit parameters while the parallel resonance is determined by the circuit parameters of $L$ and $C_{p}$ together. Table 2 summarizes the theoretical (simulation) values of the RLC circuit. The theoretical and experimental results are slightly different based on the measurement as shown in Figs. 8 to 10.

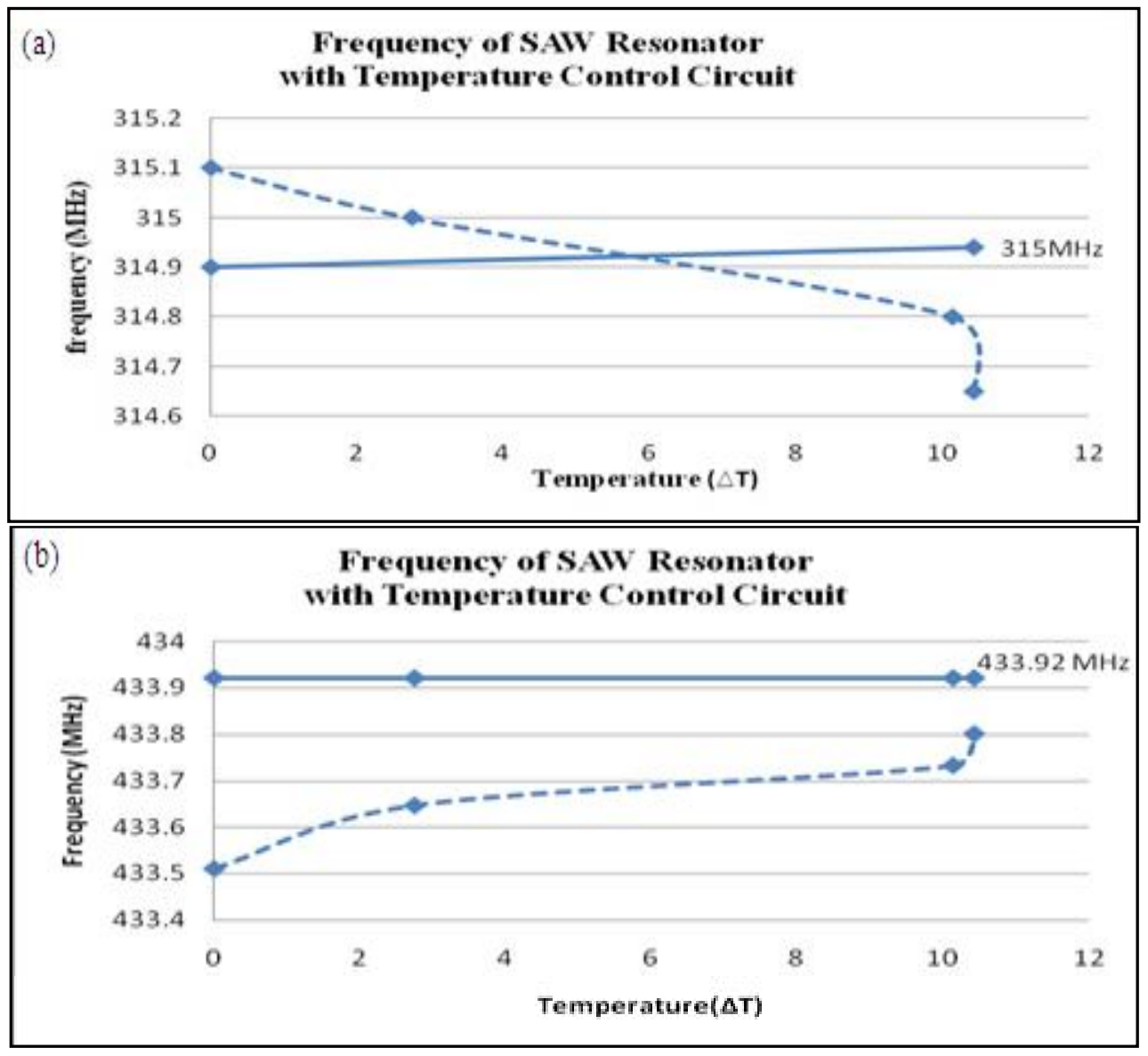




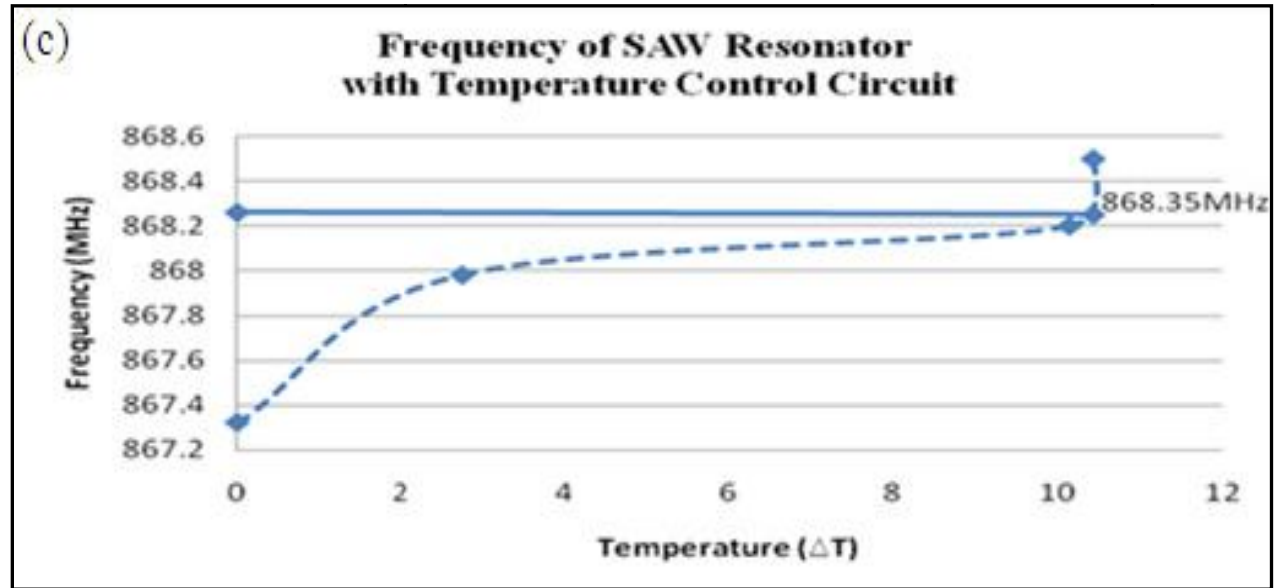

Fig. 6: Comparison for SAW resonator frequency changes with (solid line) and without (dashed line) temperature control circuit.

(a) $315 \mathrm{MHz}$ Resonator (b) $433 \mathrm{MHz}$ Resonator (c) $868 \mathrm{MHz}$ Resonator

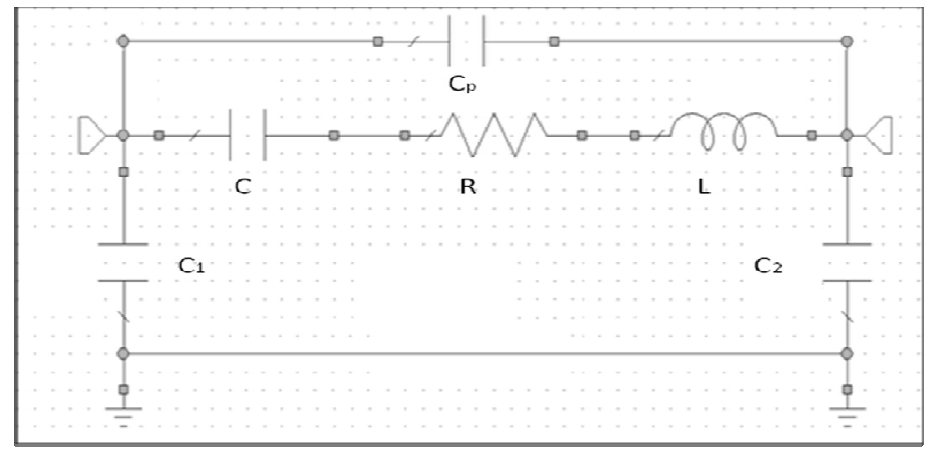

Fig. 7: Theoretical equivalent circuit for RLC of resonator.

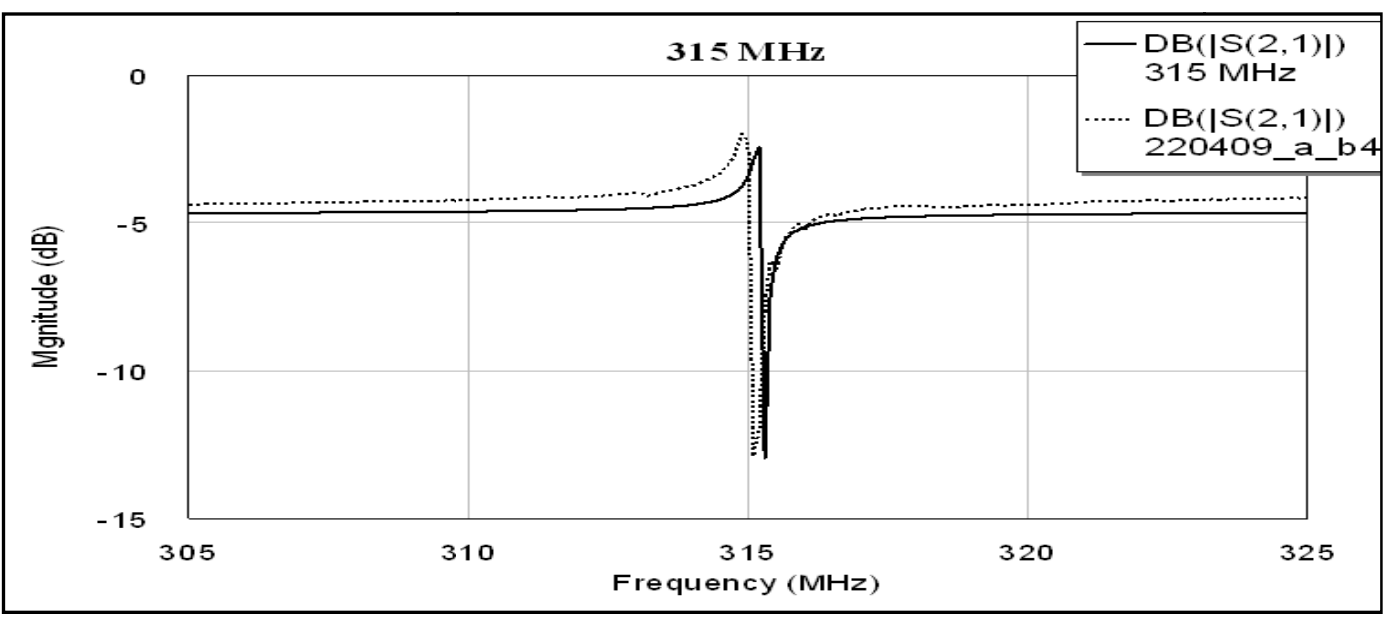

Fig. 8: Theoretical and experimental centre frequencies for RFM 315.0 MHz. 


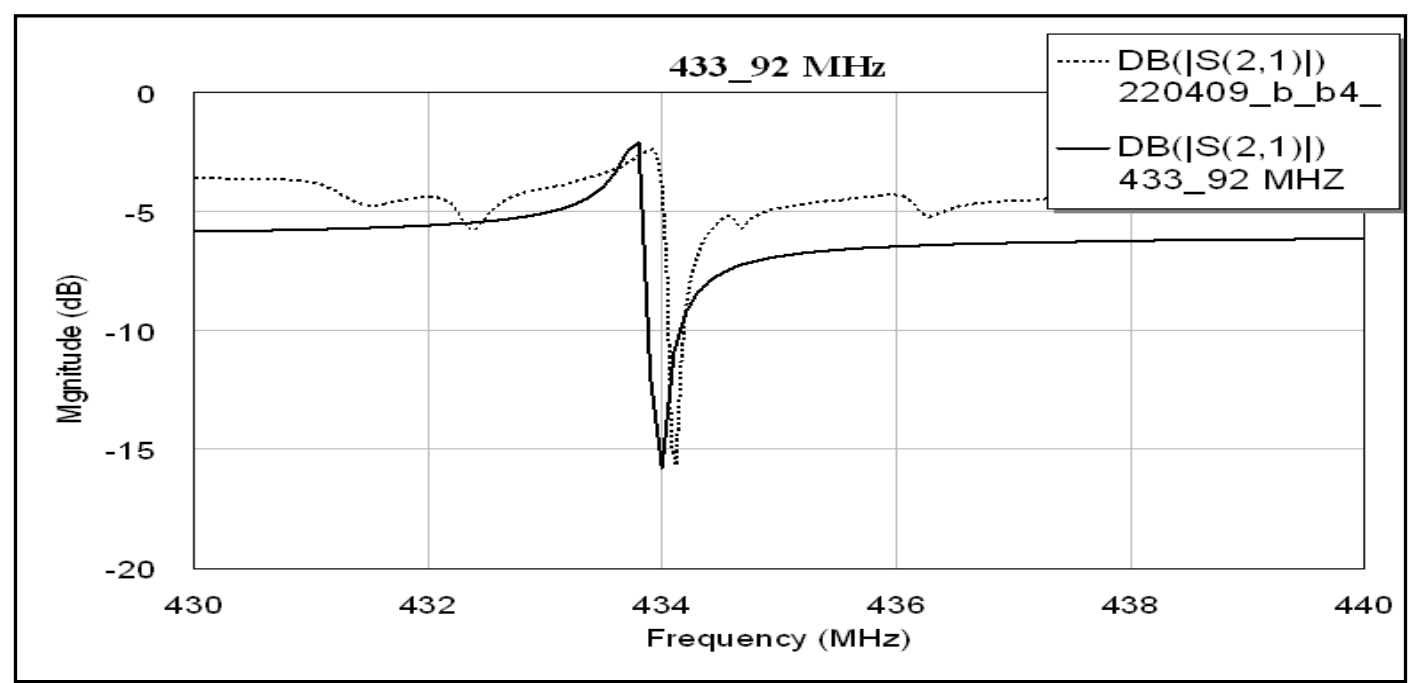

Fig. 9: Theoretical and experimental centre frequencies for RFM 433.92 MHz.

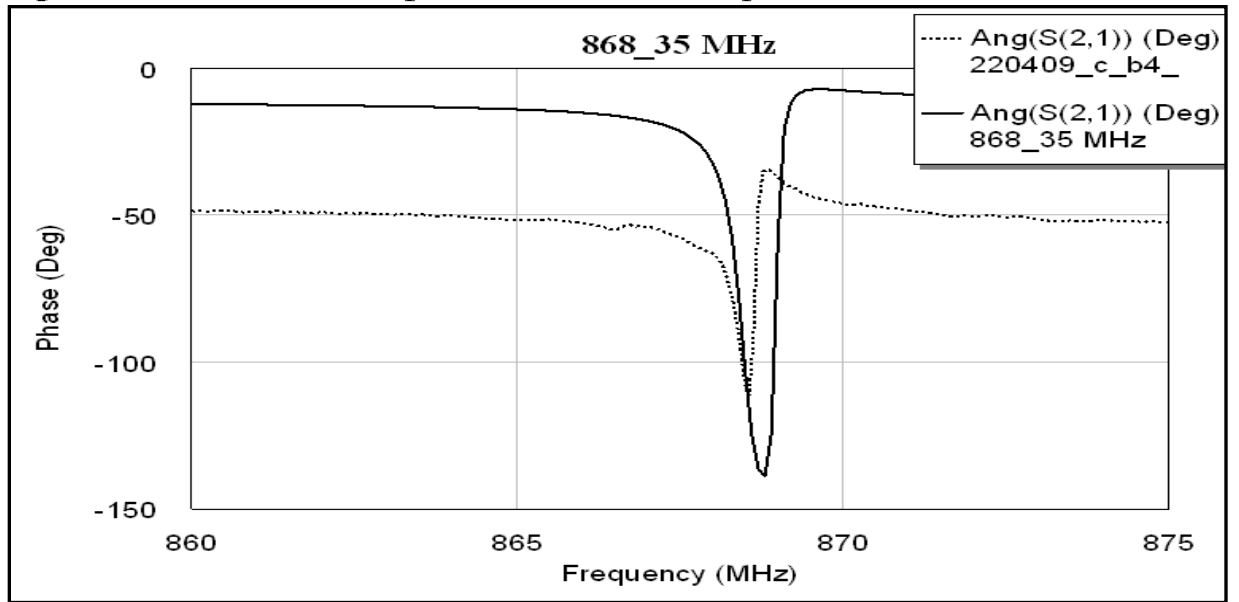

Fig. 10: Theoretical and experimental phase frequencies for ASR 868.35 MHz.

Table 1: Theoretical and experimental values for RLC circuit of SAW resonator.

\begin{tabular}{|c|c|c|c|c|c|c|c|c|}
\hline CENTRE & \multicolumn{4}{|c|}{ THEORETICAL VALUES } & \multicolumn{4}{|c|}{ EXPERIMENTAL VALUES } \\
\cline { 2 - 9 } $\begin{array}{c}\text { FREQUENCY } \\
(\mathrm{MHz})\end{array}$ & $\mathrm{R}$ & $\mathrm{C}$ & $\mathrm{L}$ & $\mathrm{C}_{\mathrm{P}}$ & $\mathrm{R}$ & $\mathrm{C}$ & $\mathrm{L}$ & $\mathrm{C}_{\mathrm{P}}$ \\
\hline 315 & $19.4 \Omega$ & $3.3 \mathrm{pF}$ & $78.4 \mu \mathrm{H}$ & $4.05 \mathrm{pF}$ & $19.4 \Omega$ & $3.32 \mathrm{fF}$ & $76.8 \mu \mathrm{H}$ & $5.99 \mathrm{pF}$ \\
\hline 433.92 & $19.4 \Omega$ & $2.11 \mathrm{fF}$ & $63.8 \mu \mathrm{H}$ & $2.35 \mathrm{pF}$ & $19.4 \Omega$ & $2.11 \mathrm{fF}$ & $63.80 \mu \mathrm{H}$ & $2.73 \mathrm{pF}$ \\
\hline 868.35 & $12 \Omega$ & $2.3 \mathrm{fF}$ & $66 \mu \mathrm{H}$ & $1.65 \mathrm{pF}$ & $12 \Omega$ & $2.3 \mathrm{fF}$ & $14.61 \mu \mathrm{H}$ & $1.33 \mathrm{pF}$ \\
\hline
\end{tabular}




\section{DISCUSSION}

This part discusses and analyzes the results and simulations obtained. Figs. 8 to 10 show the deviations in resonance frequency due to the varying temperatures. It can be seen that the resonator has a negative TCF as the resonance frequency decreases with increasing temperature. Based on (1) the TCF for each resonator without the temperature control circuit can be calculated and is shown in Table 2 .

Next, the temperature control circuit is switched on and the TEC is placed close to the SAW resonator. A second TEC is used to mimic the ambient temperature, which is varied from $28^{\circ} \mathrm{C}$ to $38^{\circ} \mathrm{C}$. As shown in Figs. 8 to 10 , the resonance frequency of the SAW resonator stays constant even with varying ambient temperature. The TCF of the SAW resonator with the temperature control circuit was calculated based on these measurements and is shown in Table 2.

The TEC results in changes of the central frequency of the SAW resonator. The samples of frequency changes were taken after about an hour of observation with the network analyzer. These samples are taken every fifteen minutes for a one hour duration. The TEC is turned on when the input voltage is smaller than the reference voltage. This condition shows that the frequency is not stabilized. It is clear that the temperature changes affect the centre frequencies of the SAW resonator. Thus, the TEC heats the $\mathrm{SAW}$ resonator until the frequency is stabilized at $50^{\circ} \mathrm{C}$. Otherwise, the heater will be turned off. The result for SAW resonators under three different conditions are shown in Fig. 6.

The purpose of designing temperature control circuit has thus been achieved. This is because the results obtained show that there are no changes in frequency of SAW resonator due to the stabilizing element produced by this circuit.

Table 2: Temperature Coefficient of Frequency.

\begin{tabular}{|c|c|c|c|c|c|}
\hline $\begin{array}{c}\text { CENTRE } \\
\text { FREQUENCY } \\
\text { (MHz) }\end{array}$ & $\begin{array}{c}\Delta F \\
(\mathrm{MHz})\end{array}$ & $\Delta \mathrm{T}$ & $\mathrm{TCF}\left(/{ }^{\circ} \mathrm{C}^{2}\right)$ & $\begin{array}{c}\text { WITHOUT } \\
\text { TEMPERATURE } \\
\text { CONTROL } \\
\text { CIRCUIT } \\
\text { TCF }\left(/{ }^{\circ} \mathrm{C}\right)\end{array}$ & $\begin{array}{c}\text { WITH } \\
\text { TEMPERATURE } \\
\text { CONTROL } \\
\text { CIRCUIT } \\
\text { TCF }\left(/^{\circ} \mathrm{C}\right)\end{array}$ \\
\hline \multirow{4}{*}{315.0} & 0.1 & \multirow{4}{*}{10.43} & \multirow{4}{*}{$3.2 \times 10^{-8}$} & \multirow{4}{*}{-136.92} & \multirow{4}{*}{12.28} \\
\hline & 0 & & & & \\
\hline & 0.2 & & & & \\
\hline & 0.35 & & & & \\
\hline \multirow{4}{*}{433.92} & 0.41 & \multirow{4}{*}{10.43} & \multirow{4}{*}{$3.7 \times 10^{-8}$} & \multirow{4}{*}{64.14} & \multirow{4}{*}{0} \\
\hline & 0.274 & & & & \\
\hline & 0.188 & & & & \\
\hline & 0.12 & & & & \\
\hline \multirow{4}{*}{868.35} & 1.03 & \multirow{4}{*}{10.43} & \multirow{4}{*}{$3.2 \times 10^{-8}$} & \multirow{4}{*}{130.44} & \multirow{4}{*}{-1.11} \\
\hline & 0.37 & & & & \\
\hline & 0.15 & & & & \\
\hline & 0.15 & & & & \\
\hline
\end{tabular}




\section{CONCLUSION}

A temperature control circuit to stabilize the SAW resonator's temperature is demonstrated. When designing the temperature control circuit, one of the main criteria of the circuit is to have constant temperature of $50^{\circ} \mathrm{C}$. A comparator is employed to compare and fix the temperature of the SAW resonator to $50^{\circ} \mathrm{C}$. Should the resonator's temperature drops to below desired temperature, the heater turns on and heats the SAW resonator, bringing it back to its constant temperature. Otherwise, the heater remains off. This simple method stabilizes the centre frequency of the SAW resonator, leading to an improvment of the overall performance of the SAW resonator.

\section{ACKNOWLEDGEMENT}

The authors are thankful to: (i) IIUM Research Management Centre for the financial assistance (Endowment Grant Type B: EDWB 0805-139) in the present investigation and (ii) the ECE Department for providing the facilities in carrying out this work.

\section{REFERENCES}

[1] M.N.Hamidon, V.Skarda, N. M. White, F.Krispel, P.Krempl, M.Binhack, and W.Buff, "Fabrication of high temperature surface acoustic wave devices for sensor applications," ELSEVIER, Sensors and Actuators A 123-124, 2005, pp. 403-407

[2] B.Drafts," Acoustic Wave Technology Sensors," IEEE Transactions on Microwave Theory and Techniques, Vol. 49, pp.795-802, No. 4, April 2001.

[3] G. Martin, R. Kunze, B. Wall, "Temperature-Stable Double SAW Resonators," Trans. IEEE UFFC-S, Vol. 55, No. 1, January 2008, pp. 199-207.

[4] A. Talbi, F. Sarry, M. Elhakiki, L. L. Brizoual, O. Elmazria, P. Nicolay, and P. Alnot, "ZnO/quartz structure potentiality for Surface acoustic wave pressure sensor," Sensors and Actuators A: Physical, vol. 128, 2006, pp. 78-83.

[5] http://www.radio-electronics.com/info/data/crystals/ocxo.php

[6] http://www.wenzel.com/documents/ocxo.html

[7] M.A. Hopcroft, "Temperature stabilized silicon resonators for frequency references", in Department of Mechanical Engineering: Stanford University, 2007, $253 \mathrm{p}$.

[8] http://www.national.com/ds/LM/LM35.pdf 
